\title{
THE INDEPENDENT LABOUR PARTY AND FOREIGN POLITICS I918-1923
}

The Independent Labour Party, which was founded in 1893 had, before the 1914-1 8 war, played a major part within the Labour Party to which it was an affiliated socialist society. It was the largest of the affiliated socialist societies with a pre-eminently working-class membership and leadership. Because the Labour Party did not form an individual members section until 19 I 8 , the I.L.P. was one of the means by which it was possible to become an individual member of the Labour Party. But the I.L.P. was also extremely important within the Labour Party in other ways. It was the I.L.P. which supplied the leadership - MacDonald, Hardie and Snowden - of both the Labour Party and the Parliamentary Labour Party. It was the I.L.P., with its national network of branches, which carried through a long-term propaganda programme to the British electorate. Finally, it was the I.L.P. which gave most thought to policy and deeply affected the policy of the Labour Party.

I.L.P. had, however, no consistent theory of its own on foreign policy before the war; rather the party responded in an ad boc manner to situations presented to it. What thought there was usually consisted of the belief that international working class strike action was capable of solving the major questions of war and peace.

That the war affected the I.L.P.'s relationship with the Labour Party is well known; the Labour Party formed an individual members section and began to conduct a great deal of propaganda on its own behalf. Also, the opposite stand, upon the question of war taken by the I.L.P. and the Labour Party, forced the Labour Party in Parliament to find non-I.L.P. leaders between 1914 and 1922. But the war also affected the I.L.P. in other ways. The party attracted a very significant section of middle class Liberal intellectuals into its ranks, and along with these it received a comprehensive programme - almost a philosophy - of foreign policy. By 1918 the I.L.P.'s foreign policy consisted of a great deal more than mere uncoordinated responses to foreign events and, at the top at least, its class composition was radically altered. 
During the 1914-18 war the I.L.P. won the support of a large number of intellectuals who had hitherto been members of the Liberal Party. Ex-Liberals such as A. Ponsonby, E. D. Morel, C. P. Trevelyan, C. R. Buxton, Seymoor Cocks, and Norman Angell had flocked into the I.L.P., the party which was nearest their point of view on the question of the war. The contact between the two groups - I.L.P. and ex-Liberals - had been made and cemented through the Union of Democratic Control, which was founded jointly by them in late $1914 .{ }^{1}$

This paper will be concerned with the effect that the newcomers had on the I.L.P. and with the tenor of I.L.P. foreign policy in the period 1918-1923.

Before proceeding to the body of the article, one preliminary point needs to be made. The new I.L.P.-ers were not primarily socialists, yet this weakness in their position within the I.L.P. was not immediately obvious. Indeed, the fact was hidden for a time by a simple accident of I.L.P. policy. Ponsonby, Morel and the rest were comfortable within the I.L.P. because the party adopted almost completely their view of the correct conduct of foreign politics. More important, they were comfortable within the party because they tied two separate political problems into one. Unemployment, always a number one policy concern for any socialist party, was made an aspect of foreign policy. To cure British unemployment it was only necessary to effect a change in British foreign policy. This point is well illustrated by C.R. Buxton's endorsement of the Divisional Labour Parties' attack on the Parliamentary Labour Party for jts failure to oppose the second reading of the Reparations Bill. He sympathised with the difficulties of the P.L.P., but assured it that the enslavement of Germany would culminate in the eventual economic degradation of Britain. ${ }^{2}$

Identification of interests was achieved by focussing attention on the problem of reparations. They argued that reparations injured both sides; the donor was hurt by an enforced low standard of life and wages, and the receiver by depriving it of a market. Further injury was done to receiving countries because their wage level was gradually

1 I have treated this liason much more fully in an article in the Yorkshire Bulletin of Economic and Social Research, Autumn, I961: The Entry of Liberals into the Labour Party, I910-I920.

${ }^{2}$ Labour Party Conference Report, 1921, p. 179. A similar point of view can be seen in the following extract from a Bradford I.L.P. resolution, "This meeting strongly protests against the proposal to cancel the Trade Agreement with Russia. It declares that the reasons alleged in no way justify either unemployment or the danger to peace which would result" - Bradford I.L.P. Minutes, I 4 th May, 1923. 
forced to a level competitive with that of the donating countries. Hence, before anything could be achieved by way of clearing up home unemployment, the priority of foreign affairs had to be conceded. H. R. Winkler has written of the new I.L.P -ers:

"At times, they mouthed the slogans of class war and almost revolutionary socialism, but it is hard to escape the conclusion that such slogans were designed to persuade the party and themselves that their programme was really a Labour programme." 1

Whilst it is true that did they mouth slogans, it was not by such sloganuttering that they were identified with socialism. The prime method was through their claim that in a correct understanding of foreign policy would be found the solution to the employment problem. ${ }^{2}$ It was by accepting this contention that the I.L.P. allowed itself to become the party par excellence dealing with foreign affairs.

Before that war the I.L.P. had been interested in international politics, or at least the leaders like Snowden, MacDonald and Hardie had. But on the whole the party had concentrated more on home policy; not one of the branch minutes available for inspection suggests otherwise. The Annual Report for the City of London I.L.P., I919, illustrates this point. It was only in March, 1914 that a Foreign Affairs Committee was formed at the request of $\mathrm{K}$. Hardie, "who believed that too little attention was paid to public events outside England." At the IIth July, I9 14 Conference of London and Southern Counties I.L.P. not one out of the I4 resolutions dealt with foreign affairs. By January, i91 5 , I 4 out of 26 were devoted to foreign affairs. By I9I 8 the party had become absorbed in foreign politics, not to the exclusion of home affairs, but the balance of interest had definitely changed. ${ }^{3}$ This change of attitudes is exemplified by an outburst in the Labour Leader of 28 th November, 1918;

"The circumstances of this election, the intrigues of Mr. Lloyd George, the prominence which is being given to domestic issues. may have the unfortunate effect of putting the vital question of the Peace Settlement into the background as an election issue."

1 Journal of Modern History, Sept., I 956. Labour Foreign Policy in Great Britain I91 8-29. 2 An I.L.P. pamphlet "Foreign Policy and the People", by Morel and Ponsonby, p. 2 (1925) makes the connection between home and foreign politics explicit when it refers to "the intimate telations between the external policy of the State... and those very issues upon which Labour was concentrating the whole of its strength."

3 For confirmation of this point see W. P. Maddox, Foreign Relations in British Labour Politics, P. 26 (Camb. Mass., 1934). 
From the beginning of I9I8 the main news-content of the I.L.P. press was foreign affairs. The I.L.P. official policy from the beginning of the war was that it was a political war resulting from the cupidity and ignorance of statesmen, rather than from the logic of capitalist development. Britain's involvement in a European War had resulted from secret agreements between the French and British governments.

"That is why this country is now face to face with red ruin and impoverishment of war. Treaties and agreements have dragged Republican France at the heels of despotic Russia and Britain at the heels of France." 1

Because this analysis of the causes of the war was in substantial agreement with the U.D.C. analysis, and because the I.L.P. from I9I4 saw its task as being a bulwark against future war, the concentration on foreign affairs is quite understandable.

It might have been expected that with the ending of the war the two disparate elements which made up the I.L.P. would have begun to fly apart. But up to late I92I the I.L.P. was united on the primary question of foreign affairs.

The intervention and blockade of Russia caused the I.L.P. to act as one body against both. Reasons for such support were legion. MacDonald and Snowden were to attack the Bolsheviks for their persecution of the Socialist Revolutionaries. But MacDonald, at least, commended Lenin and Trotsky as fighters for peace in $1918 .{ }^{2} \mathrm{~A}$ more usual I.L.P. attitude was that of Mrs. Bruce Glasier who, as editor of Labour Leader, quite specifically disassociated the I.L.P. from an attack by Snowden on the Bolsheviks. ${ }^{3}$ She argued that whatever were the excesses of the Bolsheviks, they were forced to them by the exigencies of Intervention and Blockade. With this argument the bulk of I.L.P.-ers agreed; R. C. Wallhead used a similar argument in the Labour Leader on 9 th September, 1920. So chary was the I.L.P. of seeming to attack Russia, that there arose considerable doubt in the Scottish I.L.P. on the advisability of even publishing the I.L.P. memorandum on Bolshevism to the Geneva Congress of the Second International lest it be interpreted as an attack on Russia. It was published, disclaiming any intention of attacking Russia, in Forward,

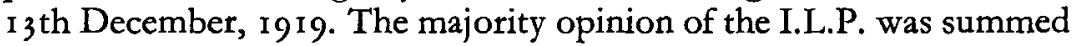
up in July I918:

1 Labour Leader, 13th Aug., 1914. The Labour Leader was an official I.L.P. newspaper.

2 Ibid., 25 th Nov., 1920 and Forward, 9th Feb., 1918.

3 Ibid., 25th Nov,, 1920. 
"In the face of the bourgeoisie which is now fighting the Bolsheviks with the calumnies of its press and bayonets of its soldiers, we are bound to place ourselves on the side of the Bolsheviks with whom we are and will remain united through the international community of the class interests of the proletariat and the common ideals of socialism. It does not, however, follow that we must share all the illusions of the Bolsheviks, approve all their methods, or accept all their theorems." 1

Marxists in the I.L.P., such as Walton Newbold, were against intervention on the ground that the attack on Russia was an imperialist adventure. This attitude was officially endorsed in the report of the N.A.C.

to the 1919 Conference, which declared that the specific intention behind the Allied interventions in Russia was the overthrow of the socialist republic. The ex-Liberals supported the I.L.P. policy on the grounds that every nation had the right to order its own internal affairs. Arthur Ponsonby at the I9I9 Annual Conference of the I.L.P. moved a resolution against intervention, arguing that the real reason for intervention and for the sacrifice of British lives was simply because the capitalist class in France, the international financiers, wanted their investments safeguarded. ${ }^{2}$ P. J. Dollan, not a U.D.C. man, whilst agreeing that imperialism was at the back of the intervention, argued that the Russian people alone were entitled to criticise, modify and adjust Bolshevik methods to conform to Russian conditions. ${ }^{3}$

The ex-Liberals tended to demand "a closing of the ranks" 4 by the workers to force an end to intervention and an alteration of the Versailles Treaty. Precisely what was meant by such phrases was left in doubt. Probably it was just an expression of exasperation with governmental policy - and their inability to influence it.

Despite these differences of opinion within the party, every section could unite on the party policy regarding Intervention. In a manifesto dated ist August 1918, the party appealed to organised labour to condemn intervention in Russia, declaring that intervention was a crime against Russian independence and the socialist revolution. Despite all its faults, the manifesto declared, the revolution was a real hope for a peaceful future.

This basic agreement was reinforced by the tendency amongst all

${ }^{1}$ Socialist Review, July, 1918. Socialist Review was the monthly theoretical journal of the I.L.P.

2 Report of I.L.P. Annual Conference, 1919, p. 73.

Forward, 8th Jan., i 921.

4 Labour Leader, sth June, igrg. 
sections of the party to see Russia as a great unopened source of future trade. Russia, it was claimed, wants everything we produce in the way of heavy capital goods and machinery, and Britain needs Russia's wheat and other raw materials. The only thing spoiling this fortunate natural phenomenon was the Government's attitude to Russia. As early as September, 1920, the I.L.P. was campaigning for a resumption of trade with Russia as a weapon against the growing unemployment. ${ }^{1}$ This plea was taken up by the 1921 Easter Annual Conference, and by November I92I, the policy had become to extend export credits to Russia. ${ }^{2}$

That the party, and indeed the whole Labour movement, was united on the Intervention question was to be amply demonstrated when direct action was discussed, and in the "Jolly George" incident, carried out. On the question of direct action to prevent arms from going to Russia's enemies, the I.L.P. was united. ${ }^{3}$

On most other questions of foreign policy the I.L.P. was equally united. It has been shown that the official I.L.P. attitude to the Great War was that it happened due to a series of secret agreements and diplomatic blunders. The party was determined that all its strength be exerted in opposing any future secret diplomacy. In an I.L.P. pamphlet - Is Britain Blameless? - written in I9I s, it was argued that if anything more important than a German defeat was to result from the war, it would be necessary to end forever "the dishonest and secret diplomacy of the British Foreign Office". " J. R. MacDonald, in an official history of the I.L.P. published in 1923 , explained that the I.L.P. stood for disarmament and a democratic control of foreign policy.

A welcome was given to President Wilson's 14 points which were seen as resembling I.L.P. policy, and the party rejoiced at the apparent change of heart which the adoption, by the Allies, of Wilson's policy was supposed to represent:

"How heretical were we when we asked for a definite statement of war aims, how unpopular when we argued that German democracy must be given a chance of acting. How craven hearted were we when we proposed a peace by negotiation anywhere

Labour Leader, 3oth Sept., 1920.

- Ibid.. I th Nov., I921.

see note of mine in Political Studies, Oct., 1961 , Ramsay MacDonald and Direct Action.

4 Pamphlet by A. F. Brockway. A similar attitude was shared by the U.D.C. men in the I.L.P. "The U.D.C. was never what is ordinarily called a Stop the Wat or Peace Society" it advocated "at the close of the wat a settlement should be adopted which instead of sowing the seeds of future conflicts, should lead to a durable and democratic peace." F. s. Cocks, E. D. Morel The Man and His Work, p. i ig(London, i919). 
else but in Berlin. But this is the sum total of President Wilson's policy." 1

By February, 1919, the brief I.L.P. flirtation with Wilson was over:

"The Paris scheme is a fraud, and it is annoying that President Wilson should have given his support to such a flagrant device to constitute Five Great Powers the dictators of the universe, with all other nations great and small existing on sufferance." 2

The I.L.P. objected to the Treaty of Versailles on a number of grounds. It had been imposed on Germany by maintaining the blockade until it was signed - hence it was not a negotiated instrument drawn up after a rational discussion. The Treaty, declared the I.L.P., could only be a scrap of paper which, under duress, the Germans would sign, but they would feel under no legal or moral obligation to follow. ${ }^{3}$

A frequent subject in the party press was the suffering of German people under the blockade which, it was argued, ensured their future bitterness and would make the Treaty valueless. Ponsonby described the blockade of Germany as leaving Britain "... desecrated in the eyes of humanity" by a disgraceful display of short-sighted chauvinism and power politics. ${ }^{4}$ The I.L.P. ran a campaign against the blockade of Russia and Germany and issued numerous pamphlets on the subject.

One of the I.L.P. objections to the constitution of the League of Nations was that it sanctioned a blockade of recalcitrant countries. 5 A wide variety of I.L.P. members united around the anti-blockade policy. Walton Newbald, the marxist, suggested that the reason for the blockade was an allied wish to steal German markets by crushing their industry. ${ }^{6} \mathrm{~J}$. R. MacDonald, on the other hand, argued that the blockade was a result of the Allies being "still in the mind of war" and was forcibly against it. ${ }^{7}$

Another extremely important reason for the party's attitude towards the Treaty was its opposition to secret diplomacy. From the beginning of the peace talks the I.L.P. detected secret agreements and spoke out against them, and its Annual Conference in I9I9 passed a resolution affirming the party's opposition to Secret Treaties. From this point of

1 P. Snowden in Labour Leader, 24th Aug., I918.

2 P. Snowden in ibid., zoth Feb., 1919. See also J. R. MacDonald in Socialist Review, July, 1919.

${ }^{3}$ I.L.P. Annual Conference Report I919, p. 4I.

- Labour Leader, sth June, 1919.

5 I.L.P. Annual Conference, 1920, pp. 87-88.

- Forward, 26th April, 1919.

? Ibid., I 7 th May, 1918. 
view alone the I.L.P. was committed to a revision of the Versailles Treaty. The party also had other objections to the Treaty.

One of the clauses of the Treaty was designed to set up an International Labour Bureau; this aroused the ire of most I.L.P.-ers, who tended to see the bureau as an "autocratic, bureaucratic set of officials". They further feared that the League was simply a capitalist conspiracy which would be charged with the task of "crushing socialism and social revolution" and argued that no time should be lost in combatting the "supreme concentration of capitalist power".

In the Labour Leader of igth December I919, J. T. Walton Newbold cursed the League as an attempt by international capitalists, headed by President Wilson, to save the world for capitalism through an organised system of "Benevolent Despotism". Even before this, the left wing of the I.L.P. had been against the League, stating that it was simply the Allies, lightly disguised as an impartial authority, and claiming wide powers of arbitration. ${ }^{1}$

Another of the party's complaints against the Treaty concerned the reparation clauses. It was agreed that for the devastated areas of France, Belgium and Italy a reparations payment was desirable, but that was all. Indeed, the I.L.P. was opposed in principle to all reparations, but accepted as politically expedient a payment to the badly damaged allied belligerents. But the party's case against reparations was firmly based on economic principles:

"Economically, it is to the interest of England to act as provider and furnisher, the banker and shipper, and so forth to a prosperous continent... the competition of millions of workers in Central Europe, with a lowered standard of living, is bound to degrade the general level of working class conditions."'

Reparations would prevent the unemployment problem in Britain from being solved, and hence a focal point for the socialist was foreign affairs. Until the Versailles Treaty had been seriously amended, there was bound to be unemployment. Consequently, socialists had to attend to, and master, foreign affairs. Philip Snowden, always one of the I.L.P.'s closest students of economics and foreign politics, argued that the postwar unemployment was directly attributable to the reparations agreements. From this he drew the lesson that until the Treaty had been amended the unemployment crisis would continue. ${ }^{3}$

The link up between reparation, unemployment and foreign policy

1 Forward, 22nd Feb, 1919.

2 C. R. and D. Buxton, In a German Miner's Home, I.L.P. pamphlet, p. 13, (Jan., 1921).

s South Wales News isth Jan., ig23. 
is also exemplified in the manifesto of prospective I.L.P. parliamentary candidates for Scotland in November 1921. ${ }^{1}$ This manifesto accepted that unemployment would result from the acceptance of the Washington Conference proposal for a to year cessation of battle ship building. Since unemployment would result, then somehow the slack had to be taken up. The solution offered was a mutual cancellation of reparation payments. A practical illustration may clarify the I.L.P. attitude. During the strike of coal miners in $192 \mathrm{I}$, the I.L.P. pointed the lesson. ${ }^{2}$ Miner's wages were being forced down, not by the perfidy of coal owners, but by reparations. Part of Germany's reparations payment was made in coal - which competed British coal out of the market - hence wages in the British coal mining industry had to come down. During the inner party struggles after 1922, H. N. Brailsford put the whole matter in two sentences. There is "a standing puzzle of Labour policy. Whilst it is primarily interested in unemployment and bad housing conditions it had had to concentrate most of its energies on foreign affairs. The puzzle is solved when the extremely close relationship of foreign affairs and home employment is recalled." 3

Payment of reparations had a connotation other than unemployment for many members of the Party. It also meant that if Germany had to pay reparations, then unilateral war guilt was established. From very early in the war the Party had fought against the idea that only Germany was to blame. No matter what attitude they had to war, I.L.P.-ers, with insignificant exceptions, ${ }^{4}$ argued that blame must be apportioned to both sides.

For the I.L.P. such a unilateral declaration of guilt was the equivalent of branding Germany as a pariah amongst nations, and as such it would cause resentment to fester in Germany and hence, constituted a potential source of conflict.

All this criticism of the Treaty and the League amounted to a rejection by the I.L.P. of both; every ranking I.L.P.er is on record as condemning them.

"The 26 Articles of the Draft of the League of Nations published at the end of last week are a challenge to the spirit and practice of democracy." 5

Philip Snowden was even more violent. "Frankly, I confess to few

1 Manifesto in Forward, 26th Nov., 1921.

2 Labour Leader, 6th May, I921.

3 New Leader, 2nd Feb., I923. The Labour Leader changed its title in the middle of 1922.

${ }^{4}$ For example, J. R. Clynes and J. Stirling Robertson.

5 J. R. MacDonald in Labour Leader, 27th Feb. 
regrets that the U.S. Senate should have destroyed the Covenant." I Ponsonby was extremely gloomy about the future:

"The Treaty is no settlement. As it stands it is the precursor of a century of strife and conflict." 2

The U.D.C./I.L.P. bloc was sorely disappointed in the actual form taken by the League and many of its deeds. They, after all, had been amongst the most important campaigners for a new and peaceable way of settling international tensions. They still supported the idea of possible peaceful settlement of disputes, but denied that, as constituted, the League could achieve such a purpose. Hence their argument was directed at the defects, not at the possibility of a neutral League of Nations. ${ }^{3}$

Experience with the League and the Treaty turned the I.L.P. antiFrench and pro-German. Always the major difficulty to any satisfactory solution of European problems seemed to be the French. Had not Britain entered the war as a result of a secret agreement with France? Was it not the French at Versailles who were demanding impossible reparations from the Germans? Was it not true that French capital had been invested in Russia? It followed that France was primarily to blame for intervention in Russia. ${ }^{4}$ With the French invasion of the Ruhr in March, 1921, everything became plain. The French demanded an impossible indemnity from Germany; indemnities were evil and, therefore, the French were malignant. Not only had they demanded the impossible, they were violating international morality in attempting to achieve it. At the 1922 Annual Conference, this anti-French attitude became quite explicit. C.P. Trevelyan demanded that a Labour Government recognise Russia immediately, "without asking leave of France", and a strong resolution was passed, condemning the French Government's attitude to Russia and asserting that every effort at arriving at an understanding had been "openly or secretly sabotaged". It was widely thought in I.L.P. circles that French policy towards Germany was designed to keep that unfortunate country perpetually weak and subservient to France. The anti-French feeling developed with much greater strength following the I922

1 Labour Leadex, 2oth May, 1919.

Ibid., I 5 th May, r919. C. P. Trevelyan criticised the Treaty and League in a letter to the Daily Herald, 2 rst May, 19 19. E. D. Morel attacked the League in Labour Leader, 2 istMay. 3 A good example of this attitude can be found in the Labour Leader, 19th Feb., 1920. "The idea of the League of Nations is a magnificent conception. In its present form the League gives neither form nor substance to this great idea."

4 Labour Leader, Ioth March, I921. Analysis by R. C. Wallhead, Chairman of the I.L.P. 
Annual Conference. Brailsford condemned the invasion of the Ruhr by Franco-Belgian forces as differing only in detail from the German invasion of Belgium in $1914 .^{1}$

Towards Germany a different attitude was adopted; they were the victims of a rapacious alliance of victors intent on bleeding her dry. It is true that socialists had always tended to feel more kindly towards Germany than France. This stemmed mainly from the fact that the Social Democrats were a powerful and influential party in Germany. However, this is not enough to account for the almost maudlin sentimentality which surrounded I.L.P. treatment of Germany. The Buxtons visited a German miner's home:

"The ornaments were one or two photos, and several very edifying mottoes, which took the place of our illuminated texts at home. 'A Cheerful guest is a burden to no one'. 'A good dish makes a happy face', or, more seriously, 'Scatter the flowers of love; guard one another from life's sorrows'." 2

So scornful was the I.L.P. of the French case put by Dr. J. S. Robertson $^{3}$ - the French were haunted by the absence of a strong frontier and the presence of a powerful neighbour - that nobody even bothered to reply to the argument.

One other feature of I.L.P. foreign policy in the period up to the Conference of April, I922, is worthy of mention. The I.L.P. nosed out wars and began finding many possible causes of war. From the I914I 8 war the I.L.P. had begun to regard itself as the British equivalent of Roman geese, giving warning when danger appeared. This task it took with great seriousness. If the I.L.P., which had been correct on the Great War, could not warn, then who could? Hence the party was ever on the look out for a war. It detected danger in the Straits and ran antiwar campaigns to avert the danger. ${ }^{4}$ In both Forward and the New Leader from October of 1922 the cause of danger was pointed out. French and British oil interests were at the bottom of the trouble between Greece and Turkey. ${ }^{5}$ From time to time, right up to the I940s the I.L.P. was doing some of its most vigorous work in this task of warning the country and the Labour Party when the danger of war appeared.

1 New Leader, 19th Jan., I 923.

2 C. R. and D. J. Buxton, In a German Miner's Home (I921). They described the departure as follows: "But none of us could quite say what we felt. As he bundled our bags into the train his face resumed its accustomed air of solemnity and the 'goodbye' was a long tight grip of the hand."

- Forward, 24th May, 1919.

- New Leader, 5 th and $13^{\text {th Oct., }} 1922$.

s See Forward, 7th Oct., I 922 for an interesting article on this subject, by R.L. Outhwaite. 
One of the noteworthy aspects of the I.L.P. in this period was that it appeared to be against everything, that so much of its policy was expressed in negative terms. It was against the League of Nations, it was against the blockade and intervention, it was against reparations, and it was against armaments; ${ }^{1}$ what was it for? The truth is that neither the U.D.C. nor the bulk of the I.L.P. were for very much: they were all in favour of open treaties, openly arrived at, but what was the content of these treaties to be? They were in favour of peace and stability, but what if another nation were not? During this period the fact is that the foreign policy of the I.L.P. rarely rose above negatives and generalities.

In this curious state of affairs two factors were of primary importance. The first of these factors was the U.D.C., the group whom A. J. P. Taylor dubbed "Dissenters".

"Dissenters still assumed that foreign affairs were unnecessary. The peoples of the world would live at peace if only they were left along. No foreign politics was still the safest rule. England should be reconciled with Germany and Russia; then the world would return to its 'normal' state of permanent peace." 2

One can scan the columns of the I.L.P. press for months at a time finding only the vaguest hints about open diplomacy coming from U.D.C. pens. Only when it came to dissenting, to denouncing did they really come into their own.

The other group contributing to this remarkable situation was that of the I.L.P. socialist-pacifists who were not concerned with the world as it was. The world as it was was a capitalist world; but everyone who knew anything about socialism understood that capitalism was the root of the world's evils: At basis the attack on the League by this group was an attack on a capitalist conspiracy; at basis the intervention in Russia was an example of capitalistic iniquity. Hence there was bound to be an air of unreality about political solutions to the world's problems. Despite many I.L.P. assertions that the great war was caused by political failures, the socialists cursed capitalism:

"The wranglings at Paris prove the truth of the I.L.P. contention that the war was essentially capitalist and imperialist in its size and objects." 3

\footnotetext{
${ }^{1}$ On the question of armaments the general dislike of the French by I.L.P.ers was once again let loose. Sec New Leader, 29th June, 1923 where the decision to double the size of the British Air Force is blamed on French militarism.

2 A. J. P. Taylor, The Trouble Makers, p. 169 (London, 1957).

3 I.L.P. Annual Conference, 1919, p. 10. See also A. F. Brockway in Labour Leader, 19th
} 
If this was the attitude of the socialists in the I.L.P., then the air of unreality which clings around the I.L.P. pronouncements on foreign policy is not difficult to explain.

A factor aggravating this air of unreality was the pacifist who saw force as being an evil, and the League's acceptance of force as the final arbiter in international relations as distasteful and unnecessary. Arthur Ponsonby deplored this acceptance of force by the League. The comments of the Labour Leader in this respect are interesting. When the U.S.A., under Wilson, intervened in Russia it had this to say:

"Pacifists may as well understand once and for all that where there's a Wilson there's no way to peace. Whether the Wilson be a Havelock or a Woodrow." 1

This was a perfectly reasonable contention accepting the basic pacifist premise of non-resistance; after all, only a change of system, not a mere change of techniques of international diplomacy, could be effective for a socialist-pacifist.

When the two major factors of I.L.P. socialism and U.D.C. "no foreign politics", together with many I.L.P.ers' pacifism, are taken into consideration, the generalities and negativisms fall into place. One of the paradoxes of post war I.L.P. history was to turn around this point; from 1922 within the party there ranged a furious debate. Was the party turning too much attention to foreign affairs - should not the party give much more attention to home politics and much less to foreign? The paradox lies in the fact that only MacDonald and a few others were really interested in foreign politics, and yet the I.L.P. paid massive attention to foreign policy after the war. Much of the post-war reputation of the party was based on its attention to foreign affairs, a field in which few I.L.P.-ers were really interested.

Thus the I.L.P., which in I914 had been a party composed almost purely of proletarians - with a sprinkling of middle class intellectuals became, in the first 6-7 years after the war, dominated by a small group of ex-Liberal middle class intellectuals. The figures involved, certainly not more than 2,000 (in I919 I.L.P. membership was approximately 40,000 ), give little indication of their influence. Many were politicians with national and even international reputations. A large number

Jan., I922: "The I.L.P. believes that the problem of poverty can only be solved, the danger of war can only be averted, by definitely re-organising human society on a Socialist basis."

1 Labour Leader, 2oth Feb., I9I9. The reference is to Havelock Wilson, a rabidly pro-war British trade unionist. 
were significant in their own localities and, almost without exception, the new recruits were inter-nationally minded. They gave to the I.L.P. or perhaps reinforced the already formed ideas of men like MacDonald and Snowden, a distinct and cohesive outlook upon the problems of foreign politics. Within the I.L.P. a peculiar combination of intellectual and practical considerations conspired to inflate the émigré Liberals into a "foreign legion" of considerable effectiveness. From within the I.L.P. their ideas soon permeated the British national consciousness and culminated in the piece of paper brandished by Neville Chamberlain. But inside the I.L.P. they formed - together with the I.L.P. old guard - the fault line along which the I.L.P. was to divide in the I920s. One section of the I.L.P., led by men such as David Kirkwood, John Wheatley and James Maxton, resented the "excessive" attention which the party paid to foreign affairs. Another section (by 1924 a minority), led by MacDonald, Snowden and the ex-Liberals, wished to concentrate on foreign affairs.

For a short time the two groups lived in a harmony reinforced by the factors already mentioned. The election of MacDonald in 1922 to lead the Parliamentary Labour Party, when both the Maxton and the ex-Liberal wings favoured MacDonald, represents the zenith of this harmony. But by 1923 the signs of a rift were becoming obvious. It is one of the minor ironies of post-war Labour history that the most important intellectual weapon in the armoury of those who lacked interest in foreign politics was supplied by an ex-Liberal, J. A. Hobson, who was passionately interested in foreign affairs. Hobson taught the I.L.P. "Little Englanders" that unemployment was caused by over-saving and under-consuming in Britain. From 1924 the battle was fought, with weapons forged in Liberal minds, between two sections of a British socialist party. The election of Maxton to the chairmanship of the I.L.P. in 1926 represented the end of the coalition (in the I.L.P.) of Liberalism and Socialism which had begun in 1914. It also marked the formal return of the I.L.P. to its pre-war position $v i s-\grave{a}-v i s$ foreign affairs. 